\title{
DUAL EDUCATION MODELS AS ELEMENTS OF CORPORATE EMBEDDEDNESS IN HUNGARY
}

\author{
Viktória Józsa \\ György Enyedi Doctoral School of Regional Sciences \\ Szent István University, Gödöllő, Hungary \\ viktoria.jozsa@gmail.com
}

\begin{abstract}
Reindustrialisation and the European Industrial Renaissance are strategic priorities of the current EU programming period (2014-2020). In parallel with the declining significance of national economies, the meso (local) level is becoming more and more powerful. Key actors of reindustrialisation are transnational companies (TNCs) and their locations, the specific settlements. Transnational companies are influential allies of local and regional communities from several aspects, such as society, economy, governance, environment, and most importantly from the perspective of the current study, science and education. Their contribution to secondary and higher level engineering education, starting from the international kindergarten level, continuing in dual education models and ending up in corporate $\mathrm{PhD}$ and MBA programs have become significant elements of the endogenous development potential of the host locations. The author considers the active participation of TNCs in these educational activities and life career model development as part of their local embedding process. Corporate embeddedness is a relatively new field of research and a phenomenon that raises several questions generating an ongoing debate between both practitioners and researchers. The current research focuses on the embeddedness of TNCs in the science and education sphere in the Central and Eastern European region, by analysing several case studies and process models from Hungary. The methodology is novel, process-based and empirical, building on the quintuple helix innovation model and the findings of recent desk-based and primary research. The contribution to the state of the art is twofold, firstly, the presentation of contemporary corporate embeddedness process models from the perspective of engineering education; and secondly, the analysis of how these processes could contribute to advanced economic growth and development path designation of an area.
\end{abstract}

Keywords: transnational companies, dual education, corporate embeddedness.

\section{Introduction}

In parallel with the declining significance of national economies, the meso (local) level is becoming more powerful. The factors of localization decisions have been re-classified and classical location theories are modified or replaced with new concepts, with a special focus on research and development (R\&D) sites. Now more than ever, Europe needs industry and industry needs Europe [1].

Corporate embeddedness is a relatively new field of research and a phenomenon that raises several questions and generates an ongoing debate between both practitioners and researchers. It has several definitions [2-5]. Some scholars insist that transnational companies are the slaveholders of Modern Age, while some others argue a mindset change and a subsequent behavioural change resulting the process of corporate embedding.

The present research was based on the empirical observation that transnational (especially German-owned) companies (TNCs) in Hungary have started to move from the status of mass production entities to strategic organisations that are influencing the life of their host community. This process is motivated primarily - but not extensively - by their economic interests with the aim of seeking and exploiting locational advantages. The author's approach sees corporate embeddedness as one kind of a local level answer to the challenges of globalisation as - accepting the theses of new economic geography - their embeddedness in the local environment could yield competitive advantage through increased exploitation of the different kinds of "relatedness" [6]. This advantage is not exclusively of an economic character, but also manifests itself in the attraction of higher valueadded activities.

One element of corporate embedding process is connected to education, more specifically to dual vocational and higher level education. In the article, the author will present corporate examples of dual education models, mainly in engineering education. Tha author examined the case studies of three transnational companies in Hungary through their subsequent development decisions and activities, in relation with their host context. The author adapted the Quintuple (Penta) Helix innovation model [7] as a basis, which is a developed form of the Triple Helix model [8], and analysed the relationship and 
embeddedness of the examined companies within the (1) local economy; (2) society; (3) science; (4) government; and (5) the natural and built environment.

\section{Materials and methods}

The research objects were large multinational companies - as formal institutions - and the author examined them in their local environment in a timeframe of 25 years between 1990 and 2015. The three Hungarian case studies were Audi Hungaria Motor Kft. in Győr, Mercedes Benz Manufacturing Kft. in Kecskemét and Robert Bosch company group in Miskolc [9].

The author followed the qualitative, inductive, empirical and company-based approach. In contrast to previous extensive research literature on local municipalities, higher education institutions and bridge organisations the processes from the companies' perspective were examined. The multi case study analysis formed a sound basis for the research and the main industrial focus was the automotive industry, even though one of the sites of Robert Bosch group in Miskolc is operating in the power tools sub-sector. The selected case studies represent well the establishing, settling and embedding process of German companies in Hungary, as they differ regarding the geographic location, development status and the economic structure, the period spent in the particular location and the position in the production chain (OEM, Original Equipment Manufacturer and Tier-1, first level supplier companies).

The settlement of Audi in Györ, in 1993, was one of the "early birds", coming soon after the change of the regime as a brownfield investment; Robert Bosch established two production facilities in Miskolc in 2001 (power tools) and 2003 (automotive); and Mercedes-Benz published its investment decision in 2008. The latter were greenfield investments. Regarding the definition of a transnational corporation the author refers to the United Nations Conference on Trade and Development (UNCTAD) as "Transnational corporations (TNCs) are incorporated or unincorporated enterprises comprising parent enterprises and their foreign affiliates. A parent enterprise is defined as an enterprise that controls assets of other entities in countries other than its home country, usually by owning a certain equity capital stake". [10]. A new status model was elaborated and proposed to visualize corporate embeddedness together with several initiatives under each dimension, and the author positioned dual education at secondary and higher level under science and international nursery, kindergarten and school under government (Fig. 1).

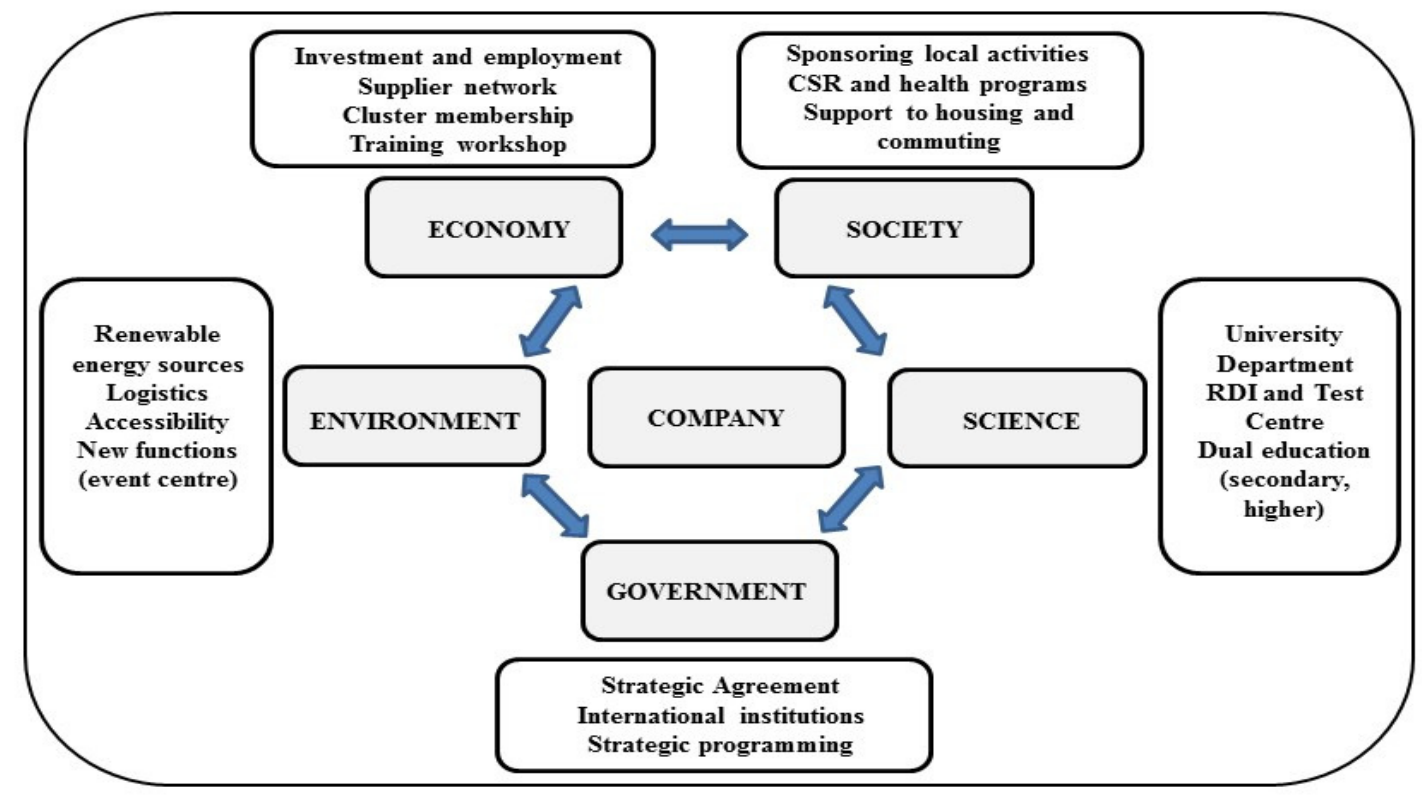

Fig. 1. Status model of corporate embeddedness (source: author's compilation, 2016)

\section{Results and discussion}

Transnational companies could have a significant impact on the designation and advancement of the development path of a specific area, especially in case of mid-size cities in the countryside with a 
population of 100,000 to 200,000 inhabitants. They could also be strategic partners of their host locations in the attraction of more foreign direct investments and high value-added activities as research and development, testing, dual education, without being exhaustive. The author's research results provided strong evidence that the depth and extent of corporate embeddedness of transnational companies is in correlation with the added value produced at the specific site.

In Hungary, intensive foreign direct investment flow has been started in the 1990s, and the research results also underline that most of the companies in the automotive sector have been started their operation between 1990 and 2000, with only one-third of the companies were established as greenfield investments [11]. The central area of automotive industry is still the Northern-Transdanubia Region, but after 2008, a differentiated development in space has also been started with the appreciation of some regions in the Eastern part of the country [12]. The author's research results identified the same tendency that is summarised in Fig. 2.
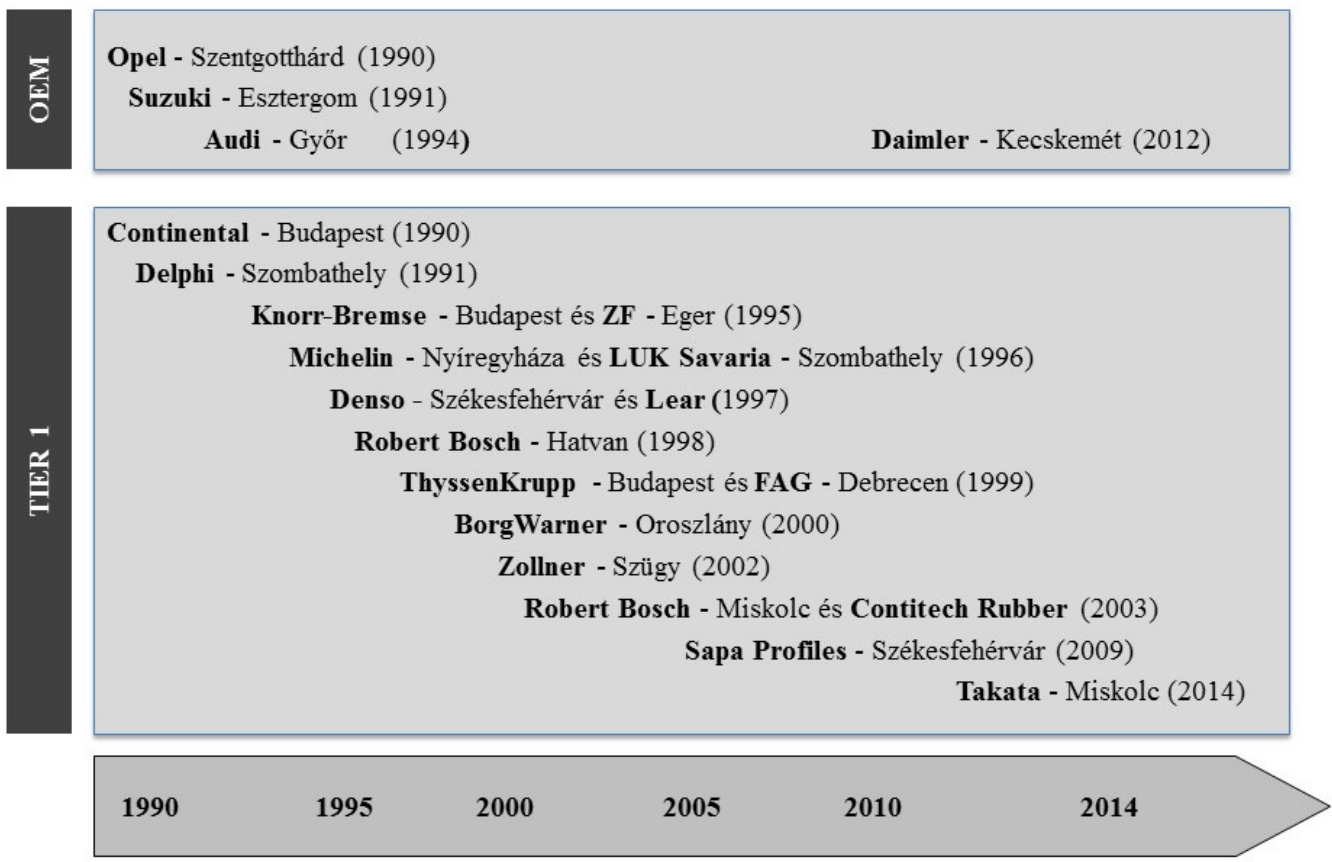

Fig. 2. Main milestones in the settlement of automotive companies in Hungary (source: author's compilation, 2016)

Dual higher education as a national level intervention was introduced in Hungary in 2015, and the decision was generated mostly by the foreign investors operating in the country. The major intention was to ensure sufficient highly educated young professionals equipped with up-to-date theoretical and practical knowledge for economy, industry and society. The basic model was the German system. Dual education is a special, practice-oriented form of higher education - mainly in engineering - that is ensured by the cooperation of higher education and industry actors. In the course of dual education, students acquire detailed and direct information about the world of work already during the period they spend in higher education, and they can become part of the work processes themselves. They can spend much more time on the acquisition and practicing of technical competences than in case of traditional education systems. In the framework of dual higher education, theoretical knowledge is gained in the higher education institution, while practical education and training are outplaced to the cooperating company. The students spend approximately the same amount of time at both locations (higher education institution and company) and they are benefiting from an allowance for the full period of their studies based on a student employment contract. The system is both beneficial to the company as a future employer and the students as future employees.

Based on the analysis of the three case studies the author elaborated a general process model for corporate embedding and identified the main phases (Fig. 3). The main phases are as follows:

Phase 1: Settling from company establishment through Start of Production (SOP) to scale-up operation, Corporate Social Responsibility (CSR) activities, dual education (at secondary and higher level); 
Phase 2: Extension capacity increase, product diversification, extensions, research and development and employee-related measures;

Phase 3: Structured Embedding other investments, new functions like renewable energy, road connection, logistics, health services, commuting, housing support, networking and strategic programming.

The author defined "compulsory" or core activities as directly connected to production and "freestyle" activities that are of a strategic character, but are not prerequisites of production. Two important factors were highlighted in connection to the identified phases as the time horizon (traditions and characteristics of the settlement and their connection with the speed of the embedding process) and the embedding protocol (the pre-designed modules and building blocks from the mother company and their tailoring and optimisation to local characteristics). The time horizon is mostly connected to the local characteristics, so the host context of corporate embedding, while the embedding protocol is largely dependent on the brought factors, such as the cultural capital and global corporate policy of the mother company, or as it is in the UNCTAD definition, the parent enterprise. Here we should highlight that the examined companies have both traditions and good practice in the field of freestyle activities, including dual higher education. In the case of Audi, for example, the company cooperates with numerous universities and research institutes in Germany and internationally pursues 12 strategic university partnerships. In 2012, approximately 130 research students were working on their doctorate through scientific projects funded by the company.

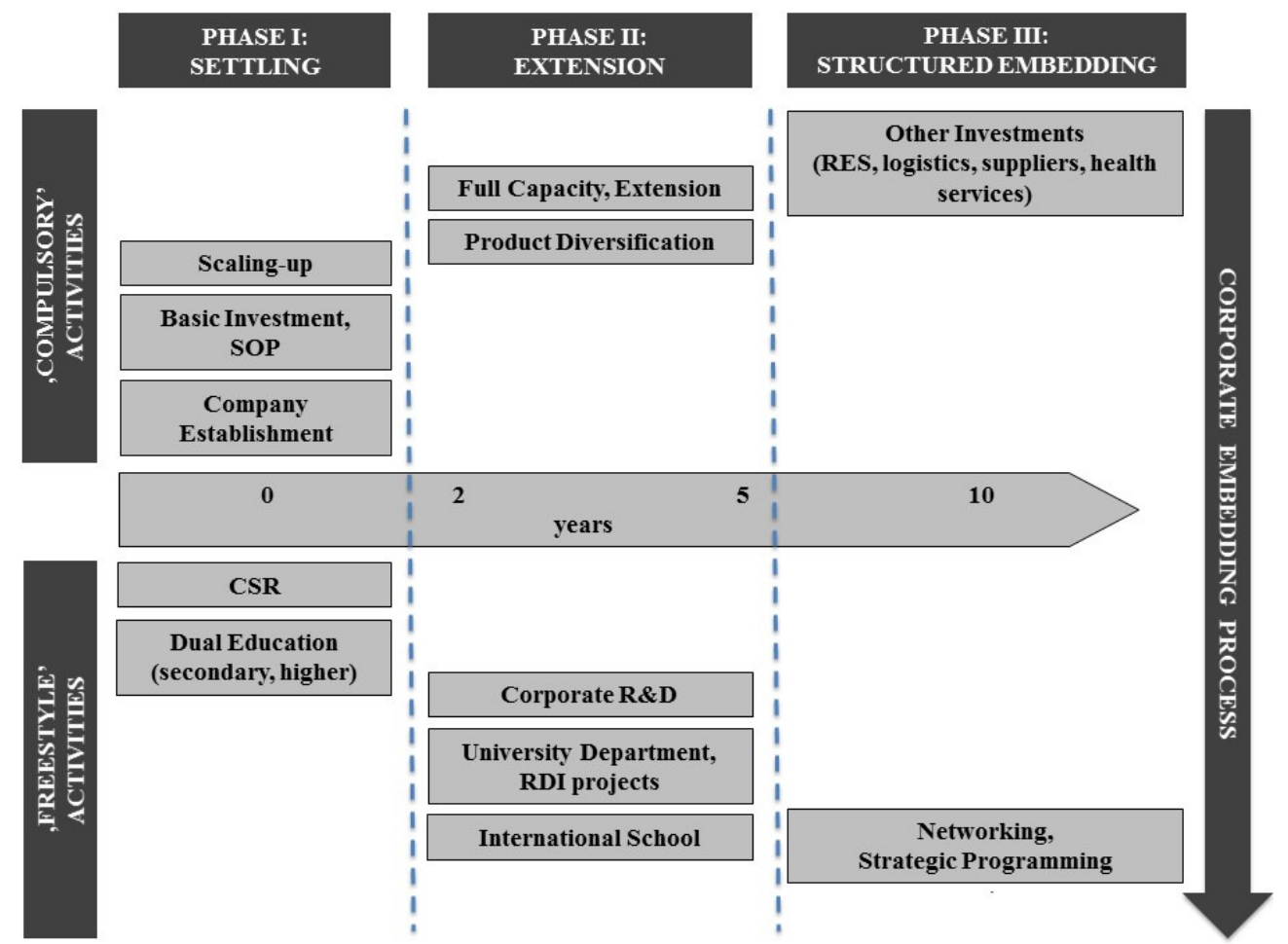

Fig. 3. Phases of corporate embedding (source: author's compilation, 2016)

As it can be seen in Figure 3, dual vocational training and higher education, together with international nursery, kindergarten and school, are part of corporate embedding.

In the field of dual higher education all three examined companies have started their cooperation with the local universities in engineering, and both Audi and Bosch have established separate university departments. Robert Bosch companies in Miskolc (North-East Hungary) established the Bosch Department at the University of Miskolc in 2004 with a main focus on mechatronics, and Audi has already established five departments in Györ (Southern Transdanubia) at the Széchenyi István University in the field of Materials Science and Technology; Internal Combustion Engines; Car Production; New Vehicle Development; and at the end of 2014, the Leadership and Organisational Communication Department. 
Regarding dual vocational education, in 2012, Audi AG at corporate level trained people in 20 locations in both technical and commercial fields with a total of 2,459 employed apprentices and dualsystem students, around 24 percent of whom were young women. The company believes that it is very important to train people for future technologies, for example, in the field of high-voltage electronics or new joining techniques.

These corporate dual education programs follow an integrated approach, as dual vocational training program gives apprentices the opportunity to obtain the entrance qualification for a university of applied sciences at the same time, qualifying as an (automotive) mechatronics technician, electronics technician or tool mechanic. Audi has been involved in the "Arbeitskreis Schule Wirtschaft" (Schools and Industry work group) for 30 years. Mercedes and Robert Bosch have also established their local dual vocational programs with the local secondary schools. The author visualised and compared the separate actions of the examined companies in the field of freestyle activities in Fig. 4. The comparison analysis leads us to two main conclusions. Firstly, that all three companies have completed both dual vocational and dual higher education programmes, and secondly, that these programs have an integrated approach from early childhood to life career models.

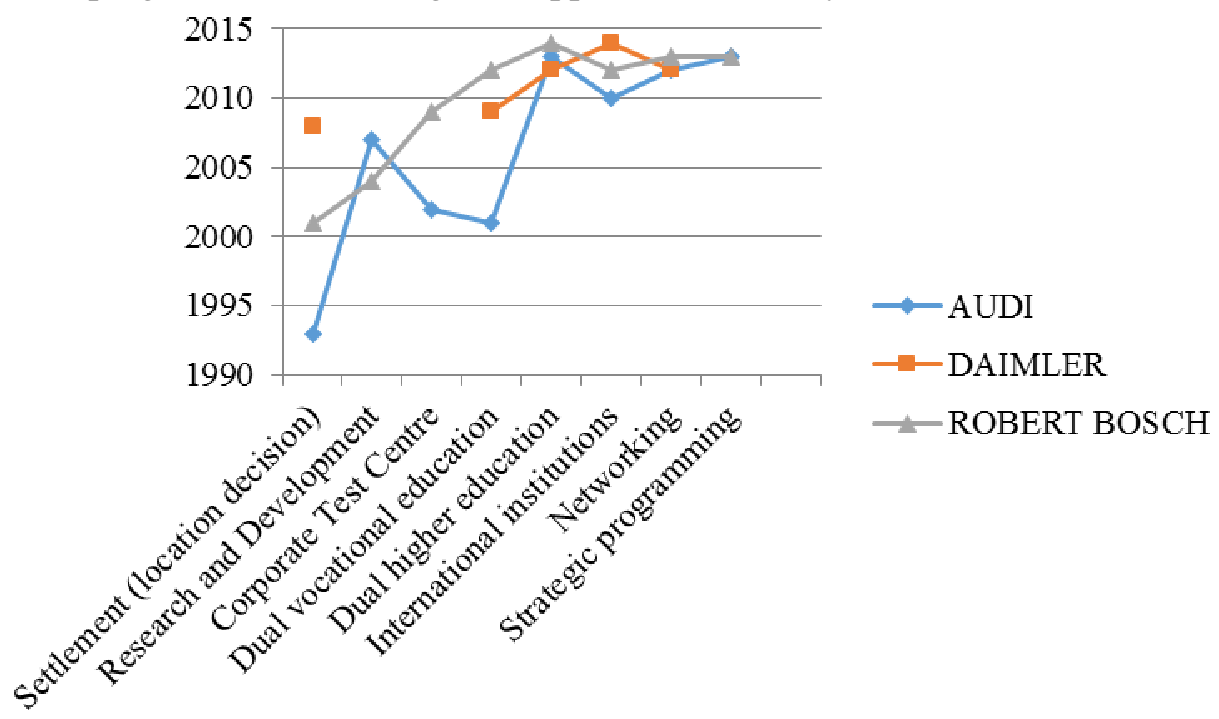

Fig. 4. Comparison of freestyle activities of the examined companies (source: author's compilation, 2016)

In case of Audi, freestyle activities (2001) have been started with a relative delay with the establishment of corporate RDI and dual vocational training. The examined period is almost 25 years. It can be argued that this relative delay was related to the "pioneer" status and the characteristics of the post-socialist environment. The local government has been active and supportive from the first moment. Today Györ is a strategic location for Audi and the cooperation has been widened to a multiplayer life career model. In case of the Robert Bosch group, two factories operate in Miskolc in two different sub-sectors. The power tool factory was established at first, and was followed by the automotive plant. The examined period is almost 15 years and the acceleration of the process can be detected. Freestyle activities were started soon after the start of production with the establishment of the Robert Bosch Department at the University of Miskolc. Dual education and international kindergarten and school followed with a small delay, but from then on, an intensive phase has succeeded. Today Miskolc is a strategic location for Bosch and there are continuous development activities within an integrated approach. In case of Mercedes, the location decision was made in 2008, but the start of production was launched only in 2012. Thepossible reasons could be the global economic crisis and the necessary to wait for a critical mass of resources from both the corporate and the local government side. The examined period is more than 5 years. The first specific feature of the case study is that dual vocational training cooperation was started right after the location decision and dual higher education, in parallel with the start of operation. Thus, a further acceleration and the repositioning of dual vocational and higher education can be observed to the very first places. The second feature is the lack of R\&D activities - as part of corporate level R\&D strategy - but a strong 
focus on international kindergarten and supplier (re)location. Daily contact and good cooperation with local government are assured.

\section{Conclusions}

1. Dual higher education recently in Hungary - mainly in the field of engineering - is an element of corporate embeddedness of transnational companies (with special focus on German companies).

2. Dual higher education is fulfilled in cooperation between (transnational) companies and higher education institutions with an integrated approach, together with international nursery, kindergarten, school, and dual vocational training. The life career model starts in an early childhood and progresses to life-long-learning opportunities.

3. From 2010, the importance of dual higher education has been continuously increasing, and recently it is positioned as one of the initial activities to be accomplished following the location decision of a transnational company.

4. Regarding corporate embedding, acceleration could be experienced in the process, and there is further significant potential in the cooperation in the field of training, education, supplier development, research and development, and strategic programming.

5. Mid-size cities are optimal locations for foreign direct investments and the future sites of the reindustrialization of Europe. Their endogenous development potential could be increased through cooperation with transnational companies as strategic allies.

6. The embedding protocol exists that includes several pre-designed modules, but local innovative solutions could occur as a result of mutual cooperation. The identification of good practices and their adaptation opportunities are crucial factors for future competitiveness of national economies.

7. Thus, further studies in the field are necessary, with special respect to cross-country and crosssectoral comparative, meso-level studies with a qualitative and process-based methodology.

\section{References}

1. European Commission. An Integrated Industrial Policy for the Globalisation Era. [online] [2010]. Available at: http://ec.europa.eu/enterprise/policies/industrial-competitiveness/industrialpolicy/files/communication_on_industrial_policy_en.pdf. 2010

2. Polányi K. The Great Transformation - The political and economic origins of our time. New York: Farrar\&Rinehart, 1944. 317 p.

3. Granovetter M. Economic action and social structure. The problem of embeddedness. American Journal of Sociology, vol. 91, 1985, pp. 481-510.

4. Beckert J. Economic Sociology and Embeddedness: How Shall We Conceptualize Economic Action? Journal of Economic Issues, vol. 37(3), 2003, pp. 769-787.

5. Nelson R.R. The Co-evolution of Technology, Industrial Structure, and Supporting Institutions. Industrial and Corporate Change, vol. 3(1), 1994, pp. 47-63.

6. Boschma R. Proximity and Innovation: A Critical Assessment. Regional Studies, vol. 39:1, 2005, pp. 61-74. DOI: 10.1080/0034340052000320887

7. Carayannis E.G., Campbell D.F.J. Triple Helix, Quadruple Helix and Quintuple Helix and How Do Knowledge, Innovation, and Environment Relate to Each Other? International Journal of Social Ecology and Sustainable Development, vol. 1(1), 2010, pp. 41-69.

8. Etzkowitz H., Leydesdorff L. The Dynamics of Innovation: From National Systems and 'Mode 2' to a Triple Helix of University-Industry-Government Relations. Research Policy, vol. 29(2), 2000, pp. 109-123.

9. Józsa V. A Robert Bosch csoport miskolci letelepedése és beágyazódásának folyamata. Tér és Társadalom, vol. 28(2), 2014, pp. 199-213.

10. UNCTAD definition of Transnational Companies. [online] [2016]. Available at: http://unctad.org/en/Pages/DIAE/Transnational-Corporations-Statistics.aspx

11. Páthy Á.; Róbert P. A járműipari beszállítók körében végzett kérdőíves felmérés módszertana. In: Rechnitzer J, Smahó M (szerk.): A jármüipari beszállítói hálózat Kelet-Közép Európában és Magyarországon. Győr: Universitas-Győr Nonprofit Kft., 2012, pp. 18-25.

12. Molnár E. Egy dinamikus iparág foglalkoztatási hatásainak földrajzi aspektusai: a magyarországi autóipar esete. Területi Statisztika, vol. 53(4), 2013, pp. 322-339. 